\title{
Designing Service Blueprint of Self-service Technology (SST) Based Public Transportation Service in Indonesia using SSTQual, Kano Model, and QFD
}

\author{
Amalia Suzianti ${ }^{1, a}$ and Arsila Chairunnisa ${ }^{2}$ \\ ${ }^{1}$ Universitas Indonesia, Industrial Engineering Department, 16424 Depok, Indonesia \\ ${ }^{2}$ Universitas Indonesia, Industrial Engineering Department, 16424 Depok, Indonesia
}

\begin{abstract}
Indonesia as one of developing countries has started to slowly implement selfservice technology to its public transportation services which are e-ticketing and e-gate. Regardless of the public's enthusiasm for these self-service technologies implemented, users' complaints regarding the services implies the importance to redesign services that are focused on user satisfaction. This study attempts to result a design recommendation method for selfservice technology based public transportation service to improve customer satisfaction by integrating SSTQual method, Kano Model, QFD and service blueprinting. Result shows that there are 12 service attributes belong to attractive category which need to be prioritized in increasing customer satisfaction. 12 attributes are then translated into technical requirements to obtain innovations to be used in the service blueprint. Through this research, there are 10 technical requirements which need to be applied to improve customer satisfaction. The technical requirements are then detailed in operational actions to be mapped in the service blueprint.
\end{abstract}

\section{Introduction}

Public service principally is under responsibility of government agencies or state-owned enterprises to fulfil community needs. This study using the case study of public railway station in Jakarta, the capital city of Indonesia. The declaration of Less Cash Society or also known as Gerakan Nasional Non Tunai (GNNT) in August 2014 has influenced the usage of self-service technology in this sector. Selfservice technology allows customers to produce services independently. Self-service technology in this case which are e-ticketing and e-gate, has started to be implemented massively in Jakarta. On the other hand, number of train passengers around Jakarta (Jakarta, Bogor, Depok, Tangerang, Bekasi) in the last 7 years has been increasing and can be said to be constantly high [1]. It indicates the importance of service quality related to this kind of public service. A preliminary study is conducted through a questionnaire involving 31 respondents resulting that there are 3 important issues to be followed up which are station's facilities, station's service procedures, and information. These types of complaints can be accommodated with planning of activities, infrastructure, communications, material components, and services or commonly referred to the service design. However, the existing service design still received a lot of complaints which indicate that improvement regarding to its

\footnotetext{
${ }^{\mathrm{a}}$ Corresponding author : suzianti@ie.ui.ac.id
} 
service quality is needed. From the previous explanation, it is necessary to redesign services that are focused on customer satisfaction which leads to the need for service redesign. The goal to be achieved in this study can be divided into three stages sequentially: (1) to analyse the voice of customers, (2) to identify the priority of innovation based on the voice of customers, and (3) to design the service blueprint related to innovation chosen.

\section{Theoretical review}

\subsection{Service design, service redesign, and service blueprint}

Service design can be interpreted as the design of services which make the service becomes easier to use [2]. Service design as an essential component in the whole development of the service process focus on basic operational development activities that involve understanding and designing interactions from a variety of physical, technology and human elements [3]. According to ISO 9004-2: 1991, service design is a process that involves changing a service description into specification for service, service delivery and control, as well as looking for options from organizations including goals, policies and costs. A good service design can provide good interaction between human, human with system, and human with environment [4,5]. Meanwhile, service redesign is a process of reconstitution, rearrangement, or replacement of processes in services where innovation in the service process will be formed [6]. This enables an organization to reassess its current service design and provide some alternative ways of delivering more effective services for customers [7]. Redesigned service can add value to customers by increasing the benefits of a service or reducing the burden of the service [8]. There are several methods used in service redesign such as user diaries, safari service, user personas, user journey mapping, design brief, business model canvas, and service blueprinting. In this study, the method used is service blueprinting. A method was found by Shostack in a study of service management regarding the service development tool [9]. This related study was further developed by Kingman-Brundage to visualize the service or service process [10]. The blueprint service is a detailed map of activities and interactions of service designed to describe all the activities required to function, both visible and invisible ones for customers. Therefore, service blueprint can objectively understand and is not influenced by the individual's point of view according to their respective roles in the service [11].

\subsection{SSTQual, Kano model, and QFD integration}

Self-service Technology Quality or usually known as SSTQual presents the basis of calculation for customer-technology interaction context in the kind of same way as ServQual applies to human interaction. It assumes a linear relationship between customer satisfaction and performance quality. The implication is that low customer satisfaction will result low quality of service. This assumption is not entirely right because of giving extra attention to certain attributes may not always result the higher customer satisfaction, otherwise customer satisfaction can also greatly increase just by giving a small enhancement to other certain attributes with sort of unexpected but pleasant service. The integration of Kano models into SSTQual can answer these limitations. The Kano model can help categorize the attributes of measuring customer satisfaction based on the relationship between performance and customer satisfaction. The integration of Kano and SSTQual models assumes that the relationship between performance and customer satisfaction is not always linear. While Quality Function Deployment (QFD) is used to translate customer requirement into a technical response that can be used to actualize customer desires. This study uses a combination of SSTQual and Kano model which is then integrated into QFD, where the research model will refer to the combined framework of ServQual, Kano model and QFD sourced from Tan \& Pawitra (2001) research. Referring to Tan \& Pawitra (2001), SSTQual is used to identify gaps between services received with expected services and collect data on the level of importance of service attributes [12]. From these two outputs, value of 
customer satisfaction score can be calculated from the service attribute. Meanwhile, the Kano model is used to identify the categories based on the kano evaluation tables. The result of customer satisfaction score and weighted kano model is then used to calculate the value of adjusted importance of service attribute in HOQ diagram.

\section{Research Methodology}

For data collection, a questionnaire of integration of the SSTQual and the kano model is distributed in this stage. Respondents involved in this study amounted to 375 people. After collecting the questionnaire data, the result of voice of customer from the questionnaire is then analysed with QFD to translate customer needs into technical responses that can be used to actualize the needs. Innovation in the form of operational action is then visualized in service blueprint to provide the details of innovation in service.

\subsection{SSTQual}

According to Lin \& Hsieh (2011) SSTQual can be used as a very useful diagnostic method to escort SST service provider from time to time. Furthermore, SSTQual research is a quality method to discover advantages or disadvantages of service and measuring the impact of improvements made. For example, an organization can use SSTQual to compare the performance of its current service with its previous service performance so that it can recognize the repetition actions that need to be applied when one of the following dimensions is below the required level. SSTQual can also be used both quantitatively and qualitatively to categorize the customer segmentation of the service provider. As customer expectations continue to change over time, service providers will gain deeper understanding of customer expectations and pain points in certain areas that have significant gaps (performances expectations) through SSTQual. The SSTQual used in this study refers to Lin \& Hsieh (2011) which consist of 7 dimensions including 20 attributes [13]. Likert scale (1-5) usage in SSTQual questionnaire for service performance and service expectation helps to determine each attribute's gap. The result of SSTQual attributes' gaps are shown in Table 1.

Table 1. SSTQual dimensions and attributes.

\begin{tabular}{|c|c|c|c|}
\hline No & Dimension & Attribute & Gap \\
\hline \multirow{5}{*}{1} & \multirow{5}{*}{ Functionality } & $\begin{array}{l}\text { I can get my service done with the firm's SST in short } \\
\text { time (FUN1) }\end{array}$ & -0.424 \\
\hline & & $\begin{array}{l}\text { The service process of the firm's SST is clear } \\
\text { (FUN2) }\end{array}$ & -0.515 \\
\hline & & $\begin{array}{l}\text { Using the firm's SST requires little effort } \\
\text { (FUN3) }\end{array}$ & -0.448 \\
\hline & & $\begin{array}{l}\text { I can get my service done smoothly with the firm's SST } \\
\text { (FUN4) }\end{array}$ & -0.267 \\
\hline & & $\begin{array}{l}\text { Each service item/function of the SST is error-free } \\
\text { (FUN5) }\end{array}$ & -0.472 \\
\hline \multirow{4}{*}{2} & \multirow{4}{*}{ Enjoyment } & $\begin{array}{l}\text { The operation of the firm's SST is interesting } \\
\text { (ENJ1) }\end{array}$ & -0.163 \\
\hline & & $\begin{array}{l}\text { I feel good being able to use the SSTs } \\
\text { (ENJ2) }\end{array}$ & -0.323 \\
\hline & & $\begin{array}{l}\text { The firm's SST has interesting additional functions } \\
\text { (ENJ3) }\end{array}$ & -0.075 \\
\hline & & $\begin{array}{l}\text { The firm's SST provides me with all relevant information } \\
\text { (ENJ4) }\end{array}$ & -0.525 \\
\hline 3 & Security/Privacy & $\begin{array}{l}\text { I feel safe in my transactions with the firm's SST } \\
\text { (SEC1) }\end{array}$ & -0.565 \\
\hline
\end{tabular}




\begin{tabular}{|c|c|c|c|}
\hline No & Dimension & Attribute & Gap \\
\hline & & $\begin{array}{l}\text { A clear privacy policy is stated when I use the firm's SST } \\
\text { (SEC2) }\end{array}$ & -0.493 \\
\hline \multirow{2}{*}{4} & \multirow{2}{*}{ Assurance } & $\begin{array}{l}\text { The firm providing the SST is well-known } \\
\text { (ASU1) }\end{array}$ & -0.067 \\
\hline & & $\begin{array}{l}\text { The firm providing the SST has a good reputation } \\
\text { (ASU2) }\end{array}$ & -0.152 \\
\hline \multirow{2}{*}{5} & \multirow{2}{*}{ Design } & $\begin{array}{l}\text { The layout of the firm's SST is aesthetically appealing } \\
\text { (DES1) }\end{array}$ & -0.523 \\
\hline & & $\begin{array}{l}\text { The firm's SST appears to use up-to-date technology } \\
\text { (DES2) }\end{array}$ & -0.384 \\
\hline \multirow{2}{*}{6} & \multirow{2}{*}{ Convenience } & $\begin{array}{l}\text { The SST has operating hours convenient to customers } \\
\text { (CON1) }\end{array}$ & -0.605 \\
\hline & & $\begin{array}{l}\text { It is easy and convenient to reach the firm's SST } \\
\text { (CON2) }\end{array}$ & -0.488 \\
\hline \multirow{3}{*}{7} & \multirow{3}{*}{ Customization } & $\begin{array}{l}\text { The firm's SST understands my specific needs } \\
\text { (CUS1) }\end{array}$ & -0.528 \\
\hline & & $\begin{array}{l}\text { The firm's SST has my best interests at heart } \\
\text { (CUS2) }\end{array}$ & -0.496 \\
\hline & & $\begin{array}{l}\text { The firm's SST has features that are personalized for me } \\
\text { (CUS3) }\end{array}$ & -0.235 \\
\hline
\end{tabular}

\subsection{Kano model}

In this study, innovation is only applied for prioritized service attributes. This priority is done so that redesign is focusing on important attributes to generate high satisfaction. In addition, it will certainly be difficult for the organization if they have to make improvements to the overall attributes since it may take longer time and higher cost. Kano model questionnaire is used for prioritizing all 20 attributes by questioning what-ifs for each attribute's functionality and dysfunctionality. Based on 20 SSTQual attributes, there are 12 attributes belong to attractive category. This study focuses on attributes that are included in attractive category because these attributes need to get more attention since they have big impacts in satisfying customer.

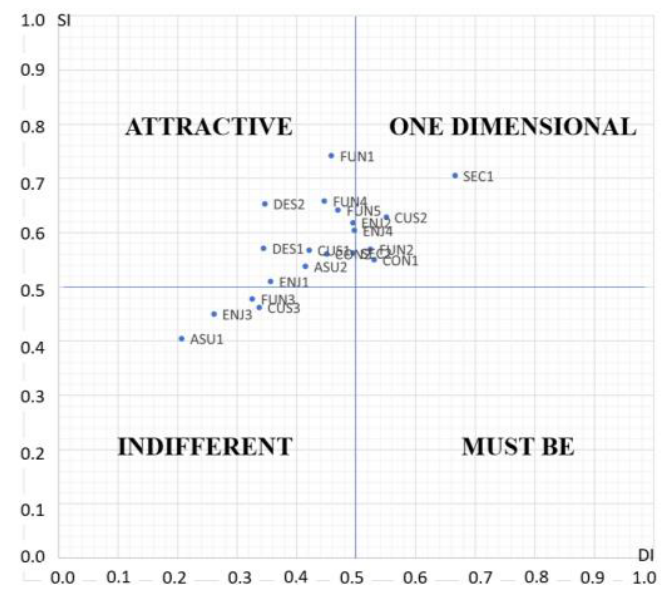

Figure 1. Kano category diagram.

Based on the results which can be seen in Figure 1, FUN1, FUN4, FUN5, ENJ1, ENJ2, ENJ4, SEC2, ASU2, DES1, DES2, CON2 and CUS1 are included in the attractive category. Based on their SI-DI values, these attributes have greatest or significant effect on customer satisfaction and least significant effect on dissatisfaction. 


\subsection{QFD}

Literature review for technical responses is conducted with inputs related to 12 attributes which results 10 corresponding technical responses. SSTQual Integration and Kano model into QFD will provide operational and systematic guidance in improving service quality by obtaining priority of these 10 technical responses. In this stage, experts are needed to determine the relationship between each customer requirement and technical requirement. These relationship scores are then used to calculate the absolute importance and relative importance of each technical requirement. The priority result from QFD where customer requirements are the 12 attributes and technical requirements are the 10 technical responses can be seen in Table 2 .

Table 2. Technical requirement priority.

\begin{tabular}{|c|c|c|c|}
\hline Technical Requirement & $\begin{array}{c}\text { Absolute } \\
\text { Importance }\end{array}$ & $\begin{array}{c}\text { Relative } \\
\text { Importance }\end{array}$ & Priority \\
\hline $\begin{array}{c}\text { Determination of supporting information facilities in } \\
\text { required spots }\end{array}$ & 266,599 & $16.91 \%$ & 1 \\
\hline Development of IT service quality support equipment & 242.746 & $15.40 \%$ & 2 \\
\hline $\begin{array}{l}\text { Procurement of information services and } 24 \text { hours } \\
\text { complaints }\end{array}$ & 196,464 & $12.46 \%$ & 3 \\
\hline $\begin{array}{c}\text { Use of social media, websites, and applications as } \\
\text { supporting activities }\end{array}$ & 187.656 & $11.90 \%$ & 4 \\
\hline Assessment of employee performance & 139.888 & $8.87 \%$ & 5 \\
\hline Implementation of preventive maintenance system & 135,943 & $8.62 \%$ & 6 \\
\hline $\begin{array}{c}\text { Implementation of knowledge management principles in } \\
\text { the company }\end{array}$ & 121,379 & $7.70 \%$ & 7 \\
\hline Implementation of user satisfaction evaluation system & 107,443 & $6.82 \%$ & 8 \\
\hline $\begin{array}{l}\text { Implementation and management of cooperating with other } \\
\text { public transportation organization }\end{array}$ & 95,738 & $6.07 \%$ & 9 \\
\hline Standardization of service time & 82,537 & $5.24 \%$ & 10 \\
\hline
\end{tabular}

\subsection{Service blueprint}

Based on the technical requirement previously formulated, before visualizing these requirements to the blueprint, there is one stage that need to be done to generate the service innovation needed in the blueprint. In this study, all 10 technical requirement priorities are used to formulate the service innovation by dividing them into three levels: strategic level (level 1), management level (level 2), and operational level (level 3). Examples of a technical requirement at all three levels can be seen in Figure 2.

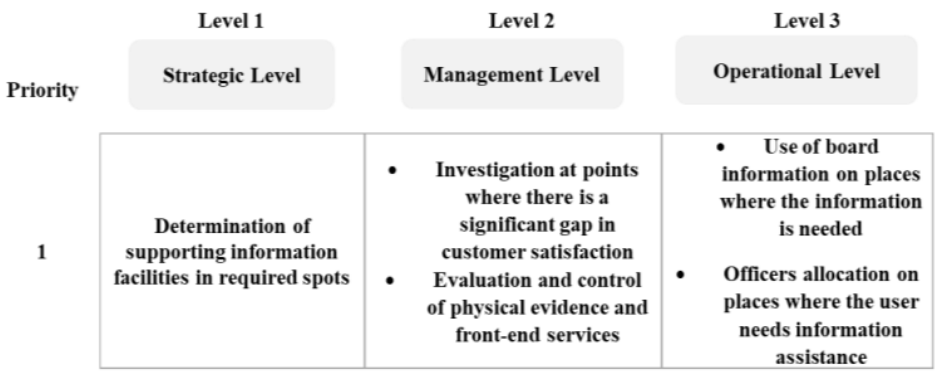

Figure 2. Technical requirement levels.

In result, 10 technical requirements in strategic level are formulated into 16 innovations (operational level technical requirement) for service blueprint. As service design focus on basic 
operational development activities, the actions that can be continued to be mapped to service blueprint are in level 3 (operational level) based on customer journey. Out of 16 actions, only 14 actions which can be mapped to the service blueprint. Those two operational actions cannot be mapped into blueprint due to their irrelevance to the customer journey of the service which should directly be related to customer.

\section{Conclusion}

Overall, the integration of SSTQual, kano model, and QFD is proven to support service redesign process specifically service blueprinting. In analysing the voice of customers, SSTQual is a right method to acquire customer expectation related to service performance by presenting the service gap between performance and expectation. In identifying the priority of innovation based on voice of customers, the integration of kano model and SSTQual helps to categorize 20 attributes of SSTQual in each category allowing service provider to choose the priority based on its goals. Since this study aims to reach high customer satisfaction, category chosen is the attractive one. In designing the service blueprint related to innovation chosen, QFD helps to translate those attributes into 10 technical responses which then formulated into three levels of action. This part is important because the flow of service blueprint is determined by customer journey so that operational actions which directly connected to customer can easily be mapped or visualized.

\section{Acknowledgements}

Thanks are due to Product Development and Innovation Laboratory - Industrial Engineering Department Universitas Indonesia, which has supported and facilitated this research.

\section{References}

1. Badan Pusat Statistik, Statistik Transportasi DKI Jakarta Tahun 2011-2017 (2017)

2. Davies, Ursula, Wilson, \& Kelly. Design Methods for Developing Services: An Introduction to Service Design and a Selection of Service Design Tools, United Kingdom: Design Council UK. (2014)

3. B. Edvardsson, B. Thomasson, J. Øvretveit, Quality of service: Making it really work, London: McGraw-Hill Book Company (1994)

4. F. I. Stuart, Designing and executing memorable service experiences: Lights, camera, experiment, integrate, action! Business Horizons, 49(2), 149-159 (2006)

5. L. G. Zomerdijk, C. A. Voss, Service Design for Experience-Centric Services, Journal of Service Research, 13(1), 67-82 (2010)

6. L. L. Berry, S. K. Lampo, Teaching an Old Service New Tricks: The Promise of Service Redesign, Journal of Service Research, II, 265-275 (2000)

7. L. Shostack, Breaking Free from Product Marketing, Journal of Marketing, 73-80 (1977)

8. V. A Zeithaml, Consumer Perceptions of Price, Quality, and Value: A Means-End Model and Synthesis of Evidence, Journal of Marketing, 2-22 (1988)

9. L. Shostack, Service design in the operating environment, Chicago: AMA (1984)

10. Kingman-Brundage, The $\mathrm{ABC}$ 's of service system blueprinting, Designing a winning service strategy (pp. 30-33). Chicago: AMA (1989)

11. Zeithaml, Bitner, Services Marketing, New York: Irwin McGraw-Hill (2000)

12. K. C. Tan, T. A. Pawitra, Integrating SERVQUAL and Kano's Model into Qfd For Service Excellence Development, Managing Service Quality, 11 (6), 418 (2001)

13. J. C. Lin, P. Hsieh, Assessing the Self-service Technology Encounters: Development and Validation of SSTQUAL Scale, Journal of Retailing, 87(2), 194-206 (2011) 